\title{
ФЕРЕНЦ ХАВАШ
}

\section{СТАЛИН-«УЧЕНЫЙ». ДИСКУССИЯ О МАРРИЗМЕ}

\section{STALIN, THE SCIENTIST. THE DEBATE ON MARRISM}

Despite emerging as a victor, the Soviet Union found itself in a deep economic crisis and was threatened by the emerging Cold War in the post-World War II period. The world power reacted to the situation with centralistic voluntarism and ideological austerity. Like all intellectual life, science too was considered worth "disciplining." Formally, this happened through seemingly scientific debates in a range of disciplines, in which winners and losers were eventually pointed out. A case in point was the debate on N. Ya. Marr's linguistic theory. But this one was not merely another episode in the series - it displayed two unprecedented features: the whole debate was running in Pravda, the daily newspaper of the Communist Party, and, quite unexpectedly, Stalin himself took part in it. The paper deals with this strange phenomenon in detail, seeking for a deeper understanding of Stalin's participation as well as a broader analysis of those ideologically-shaped disciplinary debates in the post-war period in general.

Keywords: Stalin, Marr, Marrism, linguistics, scientific debates

Ferenc Havas - D. Sc. in Linguistics, Professor Emeritus, Eötvös Loránd University, Faculty of Arts, Department for Finno-Ugric Studies. ORCID: https://orcid.org/0000-0001-6776-2470 E-mail: havas.ferenc@btk.elte.hu 
Советский Союз в военном и геополитическом смысле выиграл Вторую мировую войну, но в экономическом смысле вышел из нее в катастрофическом состоянии. Более того, довольно быстро, самое позднее к середине 1947 г., когда между блоками, возникшими в результате дележа между победителями, окончательно возникла холодная война, страна вновь оказалась в ситуации международной изоляции и конфронтации. В этой обстановке, чреватой как внешними, так и внутренними угрозами, центральная власть по устоявшейся привычке прибегла к средствам волюнтаризма и идеологической строгости.

С лета 1946 г. намерение установить контроль над интеллектуальной жизнью страны воплотилось в проведении организованных кампаний. Общее руководство этими кампаниями осуществлял, пока имел для этого физическую возможность, лично секретарь цК ВКП(б) А. А. Жданов, который считался в то время вторым человеком в Кремле и непререкаемым авторитетом (после Сталина) в научных, идеологических и культурных вопросах. Как известно, связанный с его именем жесткий идеологический курс неограниченно осуществлялся практически до смерти Сталина (5 марта 1953 г.), хотя сам Жданов скончался в середине 1948 г.

Началом волны кампаний стало постановление цК от 14 августа 1946 г. после которого была сменена вся редакция журнала «Звезда», а журнал «Ленинград» был окончательно закрыт. Вскоре после этого был закрыт или подвергнут критике целый ряд других учреждений. Позже принцип аналогии, чрезмерное рвение в выполнении директив из центра и «идейная бдительность» сделали механизм гонений более или менее самодействующим. Даже без всякого вмешательства «сверху» беспощадная борьба за культуру стала повседневным явлением, охватывая все более широкие области культурной жизни.

Вместе с тем непрерывно чувствовался контроль со стороны власти, игравший роль катализатора. Что же касается получившей особое значение сферы науки, то здесь ситуация была еще серьезнее, - в неожиданно участившихся «научных дискуссиях» того времени не только звучали голоса работников или даже руководителей центрального партийного аппарата, но активизировался и сам Сталин. Вождь лично сыграл главную роль в развертывании т. н. философской дискуссии 1947 г., ставшей первым звеном в ряду дальнейших дискуссий. Правда, он не принял в ней личного участия, но заботливо подготовил 
выступление главного оратора, Жданова, сделав в тексте выступления несколько десятков поправок и дополнений. Сама дискуссия развернулась вокруг (или скорее по поводу) книги Г. Ф. Александрова «История западноевропейской философии», за которую, впрочем, ее автору ранее была присуждена Сталинская премия. (В результате дискуссии автора обязали переработать книгу, а также осудили известный по сей день учебник С. Л. Рубинштейна «Основы общей психологии»). Сходную роль скрытой движущей силы (и правщика текста) Сталин сыграл и в хорошо известной дискуссии о генетике 1948 г., в ходе которой Т. Д. Лысенко бросился в атаку на установленные Менделем законы наследственности и менделевскую теорию генов, вместо которых он предлагал применять (переосмысленные им) идеи Мичурина. (В итоге этой дискуссии к 1948 г. советская генетика, ранее находившаяся на мировом уровне, практически была развалена, и ее обновление при жизни Сталина было невозможно.) Позже по образцу и под воздействием дискуссии о генетике ряд подобных искусственных, истерических и иногда сопровождавшихся такими же роковыми последствиями споров состоялся и в других отраслях науки, в том числе в биологии (дискуссия о теории Лепешинской), психологии (дискуссия об учении Павлова), химии (т. н. антирезонансная кампания) и т. д., и лишь в последний момент была отменена уже полностью подготовленная дискуссия об атомной физике (дабы не помешать усилиям, направленным на создание атомной бомбы).

Однако в отношении личного участия Сталина совершенно особое место должно быть отведено дискуссии по вопросам языкознания 1950 г., в ходе которой Сталин не ограничился закулисными манипуляциями и лично вступил в борьбу. В дальнейшем я подробно изложу события этого спора и дам ему оценку.

Фоном этой истории послужила сначала скрытая, а потом открытая конфронтация вокруг т. н. школы Марра в языкознании. Ее родоначальник и вплоть до своей смерти руководитель, грузинский советский академик-лингвист Н. Я. Марр (1864-1934), противопоставил свою своеобразную теорию доминировавшим ранее сравнительноисторическим лингвистическим учениям (индоевропейскому языкознанию) и, разработав свое «новое учение о языке» или

1 Суть и ход этих дискуссий, а также непосредственная или косвенная роль Сталина в них подробно описаны мною в книге: HAVAS FERENC, A marrizmus-szindróma. Sztálinizmus és nyelvtudomány (Budapest: Tinta Könyvkiadó, 2002), 368-388. 
«яфетическую теорию», создал специфически советское языкознание, которое его сторонники считали прогрессивным, более того, единственно совместимым с марксизмом. ${ }^{2}$ После смерти основателя эта школа продолжала существовать под руководством главного ученика Марра академика И. И. Мещанинова и стремилась достичь преобладания, дойдя в конце 40-х гг., пусть на короткое время, до агрессивной претензии на исключительность. На этом этапе, в том числе и под влиянием веяний, порожденных лысенковской дискуссией, она в итоге представляла уже и экзистенциальную угрозу для инакомыслящих лингвистов. Конечно, широкая публика ничего из этого не замечала и совершенно неожиданно для себя столкнулась с тем действительно не имевшим предпосылок событием, что с 9 мая по 4 июля 1950 г. противостоявшие друг другу лингвистические кружки вели борьбу не на жизнь, а на смерть прямо (и исключительно) на страницах «Правды», органа ЦК партии. Однако самой поразительной чертой завязавшегося спора было даже не это, а тот ошеломляющий факт, что в дискуссии принял личное участие и сам Сталин. В пространной статье и добавленных позже «ответах» разным лицам он осуждающе отзывался об учении Марра и, использовав аргументацию философского и лингвистического характера, отверг всю деятельность основанной Марром школы. ${ }^{3}$ Особенно резко он выступил против взглядов Марра на надстроечный и классовый характер языка. Нечего и говорить, что все это немедленно и однозначно решило исход дискуссии, включая обычные в таких случаях «организационные и кадровые выводы».

За отсутствием ясности в специальной литературе за прошедшие пятьдесят лет было сформулировано множество предположений и мифов в связи с ролью, взятой на себя Сталиным в области языкознания. Существует широкий диапазон гипотез. Среди них есть и такие, которые совершенно ничего не объясняют, как, например, мнение Хрущева, который, - быть может, в качестве поздней реакции на досаду от собственной непосвященности, - считал выступления

2 Нет возможности хотя бы в общих чертах охарактеризовать и оценить научное содержание этого учения. Эта проблематика рассмотрена мною в полном объеме в моей книге, указанной в предыдущем примечании.

3 Как с философской, так и с лингвистической точки зрения упомянутые тексты Сталина не содержали ничего, кроме тривиальных утверждений и кричащего дилетантизма. Конечно, в свое время они были овеяны нимбом гениальности, однако ныне ни один из специалистов не придает лингвистическим «трудам» Сталина ни малейшего научного значения. 
Сталина простым беспричинным капризом, ${ }^{4}$ или как попытки вывести действия Сталина из личностных качеств, характерных для любого деспота, из стремления тиранов всех времен реализовать свою неограниченную власть и в далеких от них сферах жизни, особенно в искусстве и науке. ${ }^{5}$ Сюда же я отношу и утверждения о том, что в этом случае просто победил здравый смысл, которые, однако, не объясняют, почему среди множества специалистов и идеологов только Сталин был наделен этим особым даром. ${ }^{6}$ Другая группа предположений опирается на тезис о личной неприязни Сталина к Марру. В качестве основного мотива этой неприязни указывается на ревность в связи с культом, возникавшим вокруг деятельности Марра (еще одного грузина!). Существует и мнение, что в событиях дискуссии проявилось традиционное противостояние Москвы и Ленинграда. Эти гипотезы вряд ли можно принять всерьез, ведь ранее и Марр, и Мещанинов получили множество высоких наград, причем, несомненно, с одобрения Сталина; нет никаких признаков того, что до конца 40-х гг. у вождя было какое-либо недовольство положением дел в языкознании (вероятно, оно его и не интересовало); маловероятно и то, что ревность к Марру, если она вообще существовала, кульминировала в душе Сталина спустя шестнадцать лет после смерти ее объекта. Кстати, согласно современным предположениям, нужно говорить не столько о душе Сталина, сколько о душе Берии, у которого якобы были личные счеты с Марром, и поэтому он настраивал против него Сталина. ${ }^{8}$ Наконец, имеются и гипотезы содержательного характера, согласно которым действия Сталина были вызваны просто его несогласием с лингвистическим учением Марра, и развернувшаяся дискуссия дала ему повод сформулировать свои возражения, ${ }^{9}$ или же утверждается, что

4 См.: В. М. АлпАтов, История одного мифа. Марр и марризм (Москва: Наука, 1991), 183.

5 René L'Hermitte, Marr, Marrisme, Marristes. Une page de l'histoire de la linguistique soviétique (Paris: Institut d'études slaves, 1987), 75.

6 Georges Mounin, Histoire de la linguistique (Paris: Presses universitaires de France, 1972), 240; L'HeRmitTE, Marr, Marrisme, Marristes, 75; OSWALd SZEMERÉNYI, Richtungen der modernen Sprachwissenschaft. II. Die fünfziger Jahre (1950-1960) (Heidelberg: Universitätsverlag WINTER Gmbh, 1982), 14.

7 Об этом См.: АЛПАТОВ, История одного мифа, 182-183.

8 М. В. ГОРБАНЕвский, В начале было слово... Малоизвестные страницы истории советской лингвистики (Москва: Издательство УДН, 1991), 245-247. Недостоверные слухи о неприязни Марра к Берии и якобы состоявшейся по этому поводу консультации Сталина с Берией не подтверждаются фактами и совершенно невероятны.

9 «Почему Сталин, возмутившись абсурдными, надуманными конструкциями этого Марра, не мог принять решения, - а тогда это мог сделать только он, - и просто сказать: »Довольно!«»? L'HERMITTE, Marr, Marrisme, Marristes, 75. 
истинной главной целью Сталина была реабилитация сравнительноисторического языкознания, особенно традиционной славистики. ${ }^{10}$ Есть даже и такое мнение, что своим вмешательством Сталин намеревался обеспечить возможность продвижения к формальной лингвистике, которая к тому времени давно уже доминировала на Западе..1

Перечисление гипотез можно было бы продолжить, я и сам хочу позже добавить несколько замечаний. Но уже и сказанного выше достаточно, чтобы почувствовать, насколько неоднородную картину дают эти предположения, прежде всего в том смысле, что применительно к действиям Сталина в них смешиваются вопросы почему и почему именно так. В результате этого в одних случаях предполагается, что дискуссия дала Сталину лишь форму для изложения заранее заготовленных положений, относящихся к Марру или более широким проблемам, а в других случаях, наоборот, подразумевается, что Сталин вмешался в дискуссию по каким-то внешним побуждениям и лишь задним числом определил свои взгляды. ${ }^{2} \mathrm{~K}$ тому же в построении различных гипотез играет роль еще один элемент иного характера, а именно: путаница в ответах на вопросы почему = по какой причине и почему = с какой целью, вследствие чего реальные последствия выступления Сталина рассматриваются как его изначальные мотивы, что, конечно, не обязательно соответствует фактам.

Для того, чтобы оценить эти предположения, нужно прежде всего реконструировать истинные обстоятельства возникновения дискуссии о марризме и точно определить личную роль Сталина в ней.

Нити ведут на Кавказ начала 1950-х гг. В то время там были освобождены от исполнения своих университетских и академических обязанностей профессора-армяне Ачарян и Капанцян, которые не соглашались с принципами нового учения. Однако в этом регионе СССР положение было не везде одинаковым. В Грузии не менее антимарристски настроенный профессор А. С. Чикобава находился в

10 VALENTIN KIPARSKY, „Comparative and Historical Slavistics”, in Current Trends in Linguistics. Volume I, ed. Thomas Albert Sebeok (The Hague: Mouton Publishers, 1963), 94-110. 96.

11 См., например: U. MAAS, „Parler et agir: situation de la théorie linguistique actuelle”, Sprache im technischen Zeitalter, no 41 (1972). Спекулятивную природу этого мнения хорошо демонстрирует тот факт, что антизападные настроения (в том числе и в лингвистике) не исчезли и после дискуссии о марризме.

12 Существует и предположение, согласно которому антимарровское выступление Сталина имело настолько внешнюю мотивацию, что в принципе нельзя исключить и того, что он мог бы поддержать и другую сторону. См.: BÉKÉS VERA, A hiányzó paradigma (Debrecen: Latin betűk, 1997), 237. 
хороших отношениях с партийными руководителями республики, в том числе лично с первым секретарем ЦК КП(б) Грузии К. Н. Чарквиани. Весной 1949 г. последний поручил Чикобаве подготовить работу с критикой учения Марра, пообещав переслать ее лично Сталину. 13 Текст работы, помеченный 21 апреля 1949 г., ${ }^{14}$ с опозданием в несколько месяцев действительно было передан лично Сталину (доказываемо, что Отдел пропаганды и агитации ничего не знал об этом деле).

В этой работе Чикобавы лингвистическое учение Марра подверглось резкой критике. Интересно, что о надстроечном характере языка в ней говорится лишь мимоходом, а о его классовом характере вообще нет ни слова.

После этого в течение почти года, как казалось, ничего не происходило, однако работа Чикобавы, видимо, привлекла внимание Сталина, о чем свидетельствует то, что он попросил секретарей подобрать ему для ознакомления с вопросом несколько книг по языкознанию. В начале апреля 1950 г. Чикобаве сообщили, что ему вместе с Чарквиани и другими грузинскими государственными руководителями надлежит выехать в Москву, где состоится совещание с секретарями ЦК о положении в языкознании. К удивлению прибывших вечером 10 апреля вместо секретарей их принял на своей кунцевской даче сам Сталин. (Вводящее в заблуждение приглашение, а также выбранные время и место уже сами по себе указывали на то, что Сталин придавал этой встрече частный характер). В начале беседы Сталин поинтересовался недавно выпущенным первым томом грузинского словаря, что и было официальным поводом для встречи, однако вскоре он перевел разговор на тему, связанную с Марром, дав понять, что прочитал работу Чикобавы. Поинтересовался Сталин и противниками

13 В. М. Алпатов отмечает, что существует и версия, по которой Чарквиани дал Чикобаве это поручение по приказу Сталина. Однако из-за хронологической нестыковки сам Алпатов сомневается в этом (см.: АлпАтов, История одного мифа, 181), а я просто исключаю такую возможность. В свете противоположной позиции Отдела пропаганды и агитации, а также первоначальной неосведомленности Сталина в этом вопросе невозможно представить, что вождь занимался им уже за год до дискуссии (а тем более еще раньше).

14 Позднейшая публикация: А. С. ЧикоБАВА, «Когда и как это было», в Ежегодник иберийско-кавказского языкознания, XII, (Тбилиси, 1985), 9-23. 
Mарра. ${ }^{15}$ В ходе беседы, продолжавшейся семь часов, было принято решение о проведении дискуссии, а Чикобаве было поручено написать статью, с которой и началась дискуссия в «Правде».

Чикобава остался в Москве для написания статьи. Он еще дважды побывал на даче у Сталина, где Сталин в ходе многочасовых бесед знакомился с подготавливавшимся текстом, предлагая внести в него изменения. Согласно воспоминаниям пожилого Чикобавы, с вождем можно было спорить, и иногда он позволял себя убедить. Эти беседы Сталин использовал и для того, чтобы получить от Чикобавы информацию по вопросам лингвистики, а также предложения относительно того, какую специальную литературу следовало бы еще прочитать. В то же время Сталин также, вероятно, консультировался с некоторыми специалистами, предложенными Чикобавой.

Таким образом, совершенно очевидно, что как инициатива дискуссии, так и обстоятельства, при которых она началась, зависели от решения Сталина. Учитывая кажущуюся сбалансированность, расчетливую продуманность хода дискуссии, можно утверждать, что формулировки вроде «Сталин высказал свое мнение в рамках дискуссии о марризме» или «вмешался в дискуссию» тоже являются частью мифа. Сталин не вмешался в дискуссию о марризме, а сам затеял ее. Возможно, он лично и организовал ее, но даже если и не организовал, то явно на директивах вождя основывались как принципы ее проведения, так и список приглашенных участников (при составлении которого Сталин, вероятно, опирался и на информацию, полученную от Чикобавы).

Следовательно, вопрос не в том, Сталин ли инициировал дискуссию о марризме, а в том, с какой целью он это сделал. Относительно формальной цели сомневаться нечего. Дискуссия о марризме должна

15 Произошел во многом интересный эпизод: от Чикобавы и его спутников Сталин узнал и о судьбе Ачаряна и Капанцяна. После нескольких вопросов Сталин подошел к телефону и в коротком разговоре «поставил на место» Арутюнова, секретаря ЦК КП(б) Армении. Последний, испугавшись, немедленно послал за Капанцяном (Ачарян лежал в больнице). Можно представить, что творилось в душе уже скандально снятого с должности Капанцяна, когда его подняли среди ночи и посадили в присланную за ним машину. Однако, вопреки его ожиданиям, в ЦК ему сообщили не об аресте, а о назначении директором Института языка Армянской ССР. Поняв, наконец, о чем идет речь, Капанцян ошеломленно ответил: «Неужели вы не могли подождать с этой новостью до утра?!»... (Р. МеДвеДЕВ, «Сталин и языкознание», Свободная мысль, по. 4 (1997): 110-115). Вскоре на свой пост был возвращен и Ачарян. 
была состояться именно для того, чтобы Сталин смог высказать свое мнение. Но что же было непосредственной причиной его выступления?

Не надо забывать о том, что ко времени приглашения Чикобавы и грузинских руководителей Сталин уже проявлял особый интерес к данному вопросу. Этот интерес едва ли объяснялся простым любопытством (для его удовлетворения было бы достаточно указания составить обобщающую записку об актуальном положении в языкознании), как не является достаточным объяснением и то, что Сталину, который со времени написания в 1913 г. статьи «Национальный вопрос и социал-демократия» ${ }^{16}$ считал себя специалистом по национальному вопросу, языкознание было ближе прочих общественных наук. (Правда, Чикобава пишет, что во время их бесед Сталин подходил к проблеме языка в основном именно с этой стороны, ${ }^{17}$ однако к этому нужно добавить, что это была не самая удачная отправная точка для оценки Марра, и в опубликованных статьях Сталина практически нет речи об этом вопросе). Нельзя также предположить, что Сталин уже с самого начала столкнулся с проблемой надстроечного и классового характера языка, которая позже сыграла такую важную роль в его рассуждениях, ведь, как мы уже отметили, эта проблематика практически не затрагивалась в присланной ему работе Чикобавы. Таким образом, все конкретные сведения о Марре Сталин узнал от Чикобавы и других лиц непосредственно перед дискуссией о марризме. В его текстах, опубликованных в ходе дискуссии, нельзя найти ни одного момента, который не был бы почерпнут из этого источника или из уже появившихся статей. Не одна из приписываемых Сталину мыслей была простым парафразом формулировок других участников дискуссии, некоторые свои выражения он позаимствовал из ранее опубликованных статей. Все это просто исключает всякие

16 Эту статью он написал по просьбе и, быть может, с некоторой редакторской помощью Ленина, она была опубликована в партийном общественно-теоретическом журнале «Просвещение» (1913/3-5). Это была первая статья, которую Джугашвили, до тех пор известный в социал-демократическом движении в основном как Коба, подписал псевдонимом К. Сталин. «Главным образом этой статье ее автор был обязан славой специалиста по национальному вопросу, а спустя пять лет и назначением на пост наркома по делам национальностей в правительстве Ленина». ISAAK DEUTSCHER, Sztálin. Politikai életrajz (Budapest: Európa Könyvkiadó, 1990), 123. При переизданиях эта статья многократно меняла название, ныне она известна под названием «Марксизм и национальный вопрос» (И. В. СтАлин, Сочинения. Том 2. (Москва: ОГИЗ; Государственное издательство политической литературы, 1946), 290-367.

17 А. С. ЧикобАВА, «Когда и как это было», 12. 
гипотезы о том, что замысел дискуссии может быть выведен из предварительной личной или научной неприязни Сталина к Марру или из намерения реализовать какую-либо ранее уже продвигавшуюся им лигнвистическую концепцию.

Со своей стороны, на основании всего этого я склонен согласиться с теми предположениями относительно вопроса почему, в которых изначальное и непосредственное побуждение Сталина не связывается не только с Марром, но и, вообще, с языкознанием. Работа Чикобавы заинтересовала Сталина не своим конкретным содержанием, а тем, что вождь почувствовал возможность выступить по этой тематике в качестве ученого. Однако прежде всего надо было убедиться в том, что по этому вопросу он действительно сможет сказать что-то существенное. Первоначальная работа Чикобавы была для этого слишком научной, на нее ему было трудно реагировать. Поэтому он и пригласил автора работы, попросив у него подробных разъяснений. Не исключено, что идея проведения дискуссии, скрытое предназначение которой знал, конечно, лишь сам Сталин, на самом деле возникла у него в ходе длинной беседы. Окончательно в возможности выступить Сталин, вероятно, убедился тогда, когда Чикобава уже писал статью, которой должна была открыться дискуссия. Тут Сталин, наконец, мог найти ряд конкретных идеологических моментов, о которых он считал себя способным рассуждать. С этого момента он, видимо, вел двойную игру и с самим Чикобавой, стараясь повлиять на содержание его статьи таким образом, чтобы оно сыграло ему на руку. В этом смысле наиболее резко бросается в глаза вопрос о надстроечном характере языка, ошибочность которого он, очевидно, сразу понял, но поостерегся обратить на это внимание Чикобавы. ${ }^{18}$ Между прочим, нет никаких признаков того, что Сталин заранее оповестил кого-либо о намерении принять личное участие в дискуссии. ${ }^{19}$

18 По мнению Алпатова, это нужно было Сталину для того, чтобы позже Чикобава не считал себя автором сталинских идей (АлпАтов, История одного мифа, 182). Но ведь и при опровержении утверждения о классовом характере языка Сталина не смущало то обстоятельство, что к тому времени вопрос о правильности этого тезиса Марра обсуждался уже около двадцати лет. Никто и так не подверг сомнению, что неклассовый характер языка был доказан Сталиным. Думается, что Сталина занимало не столько авторство отдельных идей, сколько желание сказать в связи с этим что-то действительно совершенно оригинальное.

19 Отмечу, что один из кардинальных вопросов сложившегося в рецепции дискуссии мифа, заключающийся в том, кто писал в действительности сталинские статьи по языкознанию, совершенно необоснован. У нас не только нет причин сомневаться в 
Рассмотрим теперь, что же могло в действительности побудить Сталина на этот шаг.

Я вовсе не утверждаю, что все действия Сталина в целом могут быть непосредственно объяснены личными мотивами. Но последними нельзя и пренебрегать, и поскольку выше я писал, что изначальные мотивы не могут быть связаны ни с Марром, ни с языкознанием, нужно начать с явно психологических мотивов.

Ныне психоаналитической характеристике личности Сталина уже посвящена специальная литература. ${ }^{20}$ Как всегда в случаях личностей тиранического типа, облик Сталина интерпретируется в аспекте компенсации комплексов неполноценности, которые стараются вывести из факторов истории физического и личностного развития, особенно из травм детского возраста. К числу наиболее часто упоминаемых моментов относятся подверженный пьянству, мучающий семью отец как древний подсознательный мотив непредсказуемого и поэтому непрерывно выслеживаемого врага, безмерно балующая сына и в качестве защитного механизма приучающая его к безгранично завышенной самооценке мать, физические недостатки Сталина, ${ }^{21}$ которые он рано привыкуравновешивать принужденно самоуверенным поведением, и тому подобное. По поводу таких рассуждений, конечно, вряд ли можно сказать что-то кроме привычных штампов вроде того, что их значение не сто́ит ни недооценивать, ни преувеличивать.

Однако я думаю, что среди предполагаемых комплексов неполноценности Сталина были и такие, с существованием которых можно более или менее легко согласиться. Сталин несомненно остерегался ученых, относился к ним с подозрением, в определенном смысле даже презирал их как мягкотелых интеллигентов, но в то же время он чувствовал мучительное желание принадлежать к их числу и завоевать их искреннее признание. Это побуждало его выступить и в качестве ученого (причем ученого в области общественных наук, поскольку его знания давали ему прежде всего такую возможность). А

авторстве Сталина, но, наоборот, есть все основания утверждать, что только он мог написать эти статьи.

20 См., например: DANIEL RANCoUR-LAFERRIERE, The Mind of Stalin. A Psychoanalytic Study (Ann Arbor, 1988). Русский перевод: Психика Сталина: психоаналитическое исследование (Москва: Прогресс-Академия, 1996).

21 Левая рука у него была короче правой, что он должен был всю жизнь учитывать при фотографировании, два пальца на левой ноге срослись, он был низкорослым, лицо его было в щербинах. 
между тем он должен был знать, знать: что бы он ни написал, советское сообщество ученых примет это с огромным воодушевлением. Настоящая проблема состояла вовсе не в том, что его будут славить, даже если он выскажет ошибочное мнение, а в том, что если даже его соображения окажутся воплощением научной истины, то причиной его триумфа все равно станет не это, а личность автора этих соображений. Однако, быть может, именно это обстоятельство и подтверждает вероятность нашего предположения. Суть дела состояла для Сталина не в научной истине, а в признании ученых.

При этом наиболее специфический душевный мотив, питавший у Сталина навязчивое стремление стать великим теоретиком, представляется еще более конкретным. Я имею в виду ту повлиявшую на всю его жизнь и поначалу более, а позже менее смешанную с уважением ненависть и ревность, которую он питал к Ленину. Дело было не просто в том, что если никто другой, то Сталин-то действительно сознавал, что Ленин считал его непригодным на роль вождя. Это можно было скрыть (как известно, это выяснилось только после XX съезда партии). Гораздо больше Сталина раздражало то, что образ Ленина, даже после смерти последнего, оставался важнейшим ориентиром не только в официальной советской идеологии (из которой Сталин беззастенчиво и с большим опытом убирал любых противников), но и в повседневном восприятии мира и истории. Было невозможно отодвинуть на задний план основателя большевистской партии и советского государства, великого классика марксизма, парадигматическую фигуру истории социалистических идей. Сталин мог освободиться от гнетущей конкуренции единственным способом обожествив Ленина 22 (и, конечно, сделав при этом себя главным жрецом нового культа). На Ленина нужно было обязательно ссылаться (читать и размышлять о его работах было необязательно), его имя, образ и дух встречались во всех текстах, на улицах и площадях, на общественных мероприятиях, но как реальная историческая личность он во времени и в пространстве отдалился от советской действительности. В результате этого в обозримой сфере человеческой жизни Сталин остался без конкурентов, в качестве своего рода земного бога.

22 Религиозное отношение к идолу Ленина намного пережило Сталина. Из многочисленных общеизвестных проявлений такого отношения хотелось бы выделить доходящий до гротеска культовый момент, когда на государственных празднествах 7-го ноября огромными рефлекторами портрет Ленина проецировали на небо (это оставалось в моде еще и при Брежневе). 
И все же было трудно примириться с тем, что Ленин, помимо своего исторического значения и престижа как политического теоретика, считался еще и классиком марксистской теории, выдающимся философом. Видимо, Сталина смущали не столько тезисы «Философских тетрадей» (он был неспособен усвоить диалектику этого произведения, но оно все равно по существу оставалось внутренним делом гуманитариев), сколько «Материализм и эмпириокритицизм», книга, с философской точки зрения гораздо менее убедительная, чем «Философские тетради», но гораздо более известная, считавшаяся основополагающим трудом по марксистской гносеологии и являвшаяся обязательной литературой для всех студентов и аспирантов. Сталина безмерно раздражало, что он не имел своей отдельной главы в истории марксизма. Конечно, «Краткий курс»23 преподавался в университетах, но это была книга по политической истории, а не по философии, что же касается не слишком пространного очерка «О диалектическом и историческом материализме», то он действительно считался философским и составлял часть официального канона, но, будучи декларировано интерпретационным, он едва ли мог считаться «творческим вкладом» в марксизм. Сталин сознавал, что в этой области ему вовсе не удалось ликвидировать преимущество Ленина (который к тому же более четверти века был мертв).

К этому надо добавить то обстоятельство, что обе упомянутые работы Сталина были созданы в 1938 г., и за прошедшие с тех пор двенадцать лет из-под его пера не вышло ни одного теоретического сочинения. Вождь почувствовал, что уже настало время блеснуть талантом ученого. И эта лингвистическая история пришлась кстати. ${ }^{24}$

Сталинский аттитюд «я - один из ученых» проявился в дискуссии о марризме и формально. Сталин не случайно настоял на том, чтобы его статья была напечатана не обособленно от статей других ученых и в точно таком же типографическом оформлении. (Это было бы невозможно, если бы решение об этом принималось редакцией «Правды».) Он позаботился даже о том, чтобы его имя фигурировало только в конце статьи и с сокращением личного имени (без указания

23 История Всесоюзной коммунистической партии (больщевиков). Краткий курс (Москва: Партиздат,1938).

24 Алпатов и другие тоже пишут о том, что одним из побуждений Сталина была жажда выступить в роли теоретика, но без упоминания о его комплексе в отношении к Ленину. Кстати сказать, как выяснилось позже, Сталин был неудовлетворен результатом, и два года спустя у него появилась охота покрасоваться в роли экономиста. 
отчества), как и в случае статей академиков. ${ }^{25}$ И, наконец, не случайно и то, что после первой статьи Сталина, которая по существу решила все вопросы, дискуссия продолжалась, на первый взгляд бесцельно. Если в том, что касается содержания статьи, Сталин не сумел устоять перед соблазном прибегнуть к наставительным поучениям, то формально он безусловно хотел подчеркнуть, что участвует в научном споре, а не закрывает его властным словом. Поэтому дискуссия формально не завершилась после его статьи. ${ }^{26}$

Вместе с тем одни психологические побуждения очень мало объясняют содержательные аспекты сталинского участия в дискуссии о марризме. Что касается самого факта выступления Сталина по вопросам языкознания, то это был отнюдь не закономерный поступок; однако это далеко не означает того, что на характер этого выступления не влияли, помимо переходящих моментов, исторические обстоятельства и приоритеты сталинского взгляда на вещи. Самое позднее во время подготовки Чикобавой начинавшей дискуссию статьи, когда, как уже говорилось, Сталину стали известны и выдвинулись на первый план идеи Марра о надстроечном и классовом характере языка, а также мотив стадиального развития языка как ряда революционных скачков, личные психологические мотивы стали второстепенными, уступив место гораздо более масштабному замыслу. Речь идет об идеологических взглядах и устремлениях Сталина, которые, конечно, далеко выходят за пределы проблематики его психологического настроя и отражают особенности социальных и исторических взглядов целой эпохи.

Втехспорах и столкновениях, в которыхсреди вех исторического пути и аспектов исторического значения Советского Союза подчеркивались, с одной стороны, революционность, международная классовая борьба, выработка и реализация пролетарских ценностей, принципы самоуправления, демонтаж государства и эмансипация народов СССР, а с другой стороны - принцип всенародности-национальности, доктрина

25 Все же в одном пункте редакторы «Правды», невзирая на все инструкции, не смогли удержаться от выражения особого почтения к вождю: имя Сталина было набрано на размер более крупными буквами, чем имена прочих авторов. Эта хитро внедренная форма выделения имени не исчезла и в случае других статей Сталина.

26 По всей видимости, решение написать вторую и третью статью было принято позже, ведь по содержанию они были связаны с реакциями на первую статью. Быть может, намерением выступить в качестве ученого объясняется и то, что на этот раз Сталину пришлось не по вкусу, чтоб дискуссия закончилась 4 июля покаяниями и осаннами. 
сильного, централизованного государства, эволютивное накопление и ведущая роль русского народа, Сталин, не считая нескольких исключений, практически всегда отдавал предпочтение последней тенденции. В его взглядах уже в годы, прилегавшие к революции 1917 г., отражались идеи т. н. национал-большевизма, ${ }^{27}$ и к 1924 г. эти взгляды воплотились в тезис о «построении социализма в одной стране». После «великого перелома», который шел вразрез с левыми политическими тенденциями, к середине тридцатых годов, концепция националистической изоляции окончательно одержала верх и в области идеологии. Были ликвидированы организации, ставившие своей целью создание по-революционному новой, пролетарской культуры и духовности (например, «Пролеткульт» и «РАПП»). Некогда провозглашавшиеся большевиками левые ценности были оттеснены в декларативные доктрины учебников, а отчасти исчезли даже и оттуда. Победившая идеология непосредственно отразилась и в смене курса общественных наук, прежде всего исторической науки, который получил националистическую направленность, был нацелен на возрождение традиций. Позже эти тенденции были до крайности усилены как в официальной идеологии, так и мировидении Сталина мировой войной и последовавшей за ней эпохой холодной войны: в бюрократическом менталитете с невиданной ранее откровенностью проявились националистический мессианизм и великодержавные амбиции. Несмотря на по-прежнему звучавшие доктринальные декларации, все это, конечно, уже не имело ничего общего с некогда провозглашавшимися левыми революционными идеями.

Что касается ультранационалистических тенденций, то их отождествление несколько затрудняется идеологической практикой, в рамках которой, быть может, не всегда преднамеренно, а по причине принципиальной непроясненности вопроса, понятие исторического субъекта колебалось между самообразами «мы, советские люди» и «мы, русские люди». Однако нет сомнений в том, какой момент считался более весомым. Когда Сталин, которого с уверенностью можно назвать новообращенным русским, в своем знаменитом тосте, произнесенном в Кремле 24 мая 1945 г., провозгласил здравицу не советскому, а русскому народу, без обиняков назвав его наиболее

27 CM.: D. Csurakov, „A nacionálbolsevizmus keletkezési idejéről”, in Dokumentumok történeti ruszisztikánk tárgyköréből, szerk.: HAVAS FERENC (Budapest: Magyar Ruszisztikai Intézet, 2000), 120-125. Первоначально: Альтернативы, по. 2 (1998): 84-88. 
выдающимся из всех народов СССР, он тем самым однозначно наметил курс на будущее. ${ }^{28}$ С этого, точнее, по крайней мере с этого времени СССР практически воспринимался как расширенная Россия (как позже и восточный блок - как расширенный СССР).

В годы, последовавшие непосредственно за победной войной, советский патриотизм в течение некоторого времени еще оставался более сильной тенденцией, чем русофилия. Однако колебания длились недолго. К 1948 г. русификация высшего и среднего образования дошла до того, что провозглашение первенства отечественных научных и культурных достижений было доведено до абсурда. Это одновременно искажало оценку как своих, так и зарубежных творческих результатов.

Конечно, ультранационалистическая идеология служила лишь укреплению структуры власти и прежде всего позиций самого Сталина. Его культ личности, существовавший уже долгие годы и усилившийся до степени религиозного поклонения после победы в войне, достиг кульминации в 1949 г., в грандиозных торжествах по поводу семидесятилетия вождя. Никто и ничто не могло ограничить его власть. Несмотря на это, от все чаще избегал личных публичных выступлений и стремился, даже иногда в обход собственного аппарата, управлять событиями закулисно, со своей кунцевской дачи.

Эта все в большей степени управляемая собственными законами склонность Сталина к подозрительности и изощренному маневрированию проявилась и в том эпизоде, который стал здесь предметом нашего анализа. Если бы Сталин доверил подготовку лингвистического выступления своему идеологическому аппарату (Агитпропу), то у него были бы хорошие шансы принять участие в дискуссии на противоположной стороне. И не только потому, что сам Агитпроп никогда не искал информации у антимарристов, а

28 «Я пью, прежде всего, за здоровье русского народа потому, что что он является наиболее выдающейся нацией из всех наций, входящих в состав Советского Союза. Я поднимаю тост за здоровье русского народа потому, что он заслужил в этой войне общее признание, как руководящей силы Советского Союза среди всех народов нашей страны. Я поднимаю тост за здоровье русского народа не только потому, что он - руководящий народ, но и потому, что у него имеется ясный ум, стойкий характер и терпение». И. В. СтАлин, О Великой Отечественной войне Советского Союза (Москва: Политическая литература, 1950), 196. См. еще: NICOLAS WERTH, Histoire de l'Union Soviétique: De l'Empire russe à la Communauté des États indépendants 19001991 (Paris: Presses Universitaires de France, 1990). Русский перевод: Н. ВЕРт, История советского государства. 1900-1991 (Москва: Прогресс, Прогресс-Академия, 1992; второе издание: 1994), 340. 
потому, что в этом случае резкий антииндоевропеизм Марра мог показаться настолько хорошо соответствующим одной из самых устойчивых идеологических аксиом сталинского мышления и атмосферы холодной войны, вере в превосходство советской науки, что часть антимарристских аргументов, быть может, вообще не возникла бы. Однако Сталин, не сознавая того, «организовал» себе сбор информации у таких людей, которые, мягко говоря, не желали чрезмерно акцентировать этот аспект воззрений Марра. И в результате этого в идеологические сети попалось не антизападничество, а прежде всего мотив классового характера языка, ${ }^{29}$ нечто такое, что, как бы ни трудно это было представить, тогда уже долгое время принадлежало в глазах Сталина к числу подозрительных категорий.

Не то чтобы взгляды такого рода выходили за рамки ультранационалистической идеологии. Ясно, что русофилия, принцип национального единства как государственный интерес противоречат ленинскому понятию о «множестве наций в одной нации» и марксовому понятию классовой борьбы. В официальной доктрине, конечно, продолжала существование терминология класса и классовой борьбы, однако о наличии классовых противоречий, особенно антагонистических, внутри советского общества в принципе уже не могло быть и речи. ${ }^{30}$ Изначальное представление о том, что структура основных противоречий в обществе является вертикальной, со второй половины тридцатых годов и особенно в послевоенный период сменилось представлением о горизонтальной структурированности. В глобальных масштабах классовая борьба все отчетливее воспринималась таким образом, как будто Советский Союз играл в ней роль пролетариата, а западный блок - роль эксплуататоров, естественно, обреченных на

29 И уж конечно не его надстроечный характер, с которого будет начинаться опубликованная статья Сталина. С идеологической точки зрения его значение уступало важности тезиса о классовом характере языка, это скорее было логическим следствием отрицания классового характера, большей частью простым важничанием.

30 При этом об иррациональном волюнтаризме идеологии ничто не свидетельствовало лучше того, что на практике речь о них все же шла: классов не существовало, но, согласно сталинской доктрине, классовая борьба все время обострялась. Это непостижимое противоречие пытались разрешить отчасти указанием на пережитки, использованием мифа о яростном сопротивлении горстки реакционеров, а отчасти упорным утверждением непосредственного диверсионного вмешательства Запада. 
гибель. ${ }^{31}$ Однако такое понимание подрывало первоначальный смысл соответствующих идеологем. Категория классового характера вместе с революционностью, интернационализмом и т. д. принадлежали к числу тех ключевых понятий, которые Сталин уже в течение долгого времени очень хотел отодвинуть на задний план, хотя, будучи «отцом народов», никогда не признался бы в этом открыто.

Классовый характер и революционные скачки. Когда Сталин обнаружил в теории Марра (точнее, в доступной ему интерпретации этой теории) такие мотивы, которые, казалось, были созвучны этим раздражающим его категориям, по существу опредилилось и то, чью сторону он примет в споре. Очевидно, высмотрев для себя эти мотивы, он вовсе не имел намерения пропесочить одного только Марра. Вероятно, его не очень-то интересовало, что именно говорил об этом марр, суть была в том, что хотел сказать по этому поводу он сам.

Критикуя маррову концепцию языка и его развития, Сталин явно руководствовался такой а priori идеологической мотивацией. Когда он понял, что в этом понимании глобальная судьба языка связывается с такими принципами, которые оттесняют на задний план или вовсе исключают идею различия языков, а тем более превосходства некоторых из них, ему стало ясно, что лингвистическое учение Марра непригодно для обоснования завышенной самооценки нации. А между тем язык, согласно одобренной самим Сталиным дефиниции, занимал центральное место среди критериев нации. Далее, из превозношения русского языка следовала высокая оценка всех

31 Переход от «вертикального» понимания классовых противоречий к «горизонтальному» заметен и в сфере государственного регулирования науки. В 20-х годах, до начала тридцатых годов положительным антиподом «буржуазной» науки, в целом объявленной противником или врагом, еще считалась «пролетарская» наука. При оценке деятельности конкретных лиц главным критерием была классовая, а также партийная принадлежность данного ученого. Требование «партийности» отражало тот же самый классовый подход, что и сталинский тезис об обострении классовой борьбы. Зато со второй половины 30-х гг., параллельно с «построением основ социализма» и складыванием сталинской имперской политики, в противопоставлении «буржуазного» и «небуржуазного» все больше проявляется «патриотический» акцент. Нарастала критика зарубежной науки, принимались административные меры по ограничению контактов с иностранными учеными. В отечественной науке уже разоблачались «апологеты буржуазной науки». В послевоенный период окончательно утвердился взгляд на исключительную прогрессивность советской науки (и культуры). См.: Н. Л. КРеменцов, «Равнение на ВАСХНИЛ», в Репрессированная наука. Выпуск II, ред. М. Г. ЯРошевский (СанктПетербург: Наука, 1994), 83-95. 
славянских языков. А поскольку славянские языки невозможно было объединить в единую группу иначе, как в рамках понятия языковой семьи, как это делалось в индоевропеистике, на которую резко нападал Марр, возникала необходимость реабилитации понятия языковой семьи и историко-сравнительного языкознания.

Вместе с тем рассуждения об экономическом базисе и безусловно подчиняющейся ему надстройке, предлогом для которых стала проблема языка, дали возможность Сталину с помощью аподиктических социально-философских аргуменов засвидетельствовать между строк неоспоримую необходимость существующего партийногосударственного строя, концентрации политической власти и господства единственной идеологии. ${ }^{32}$

Вдалбливание идеологических директив под предлогом обсуждения возникшей лингвистической проблемы - вот в чем состояла, следовательно, истинная движущая сила сталинского выступления. ${ }^{33}$ Что бы ни думали об этом историки языкознания за прошедшие пятьдесят лет, все моменты специально лингвистического характера играли в мотивации Сталина только второстепенную роль.

Тем не менее, в конечном итоге нельзя отрицать и существования этого третьего мотивационного слоя. Сталин считал себя компетентным с двух точек зрения - как политик, определяющий судьбы науки, и (вопреки притворно скромным вступительным словам первой статьи) как специалист по языку. Нет сомнений, вождь действительно чувствовал, что на основании прочитанного и полученных консультаций он может позволить себе выступить и в роли языковеда. Он, вероятно, с наслаждением излагал свои мысли в этой даже в своей периферийности эксклюзивной научной области (в чем только не разбирается тот, кто разбирается в лингвистике!), ему самому импонировало, что он с такой безграничной уверенностью рассуждает о таких терминах, как словарный запас, грамматика, диалекты, жаргоны

32 Верт считает это важнейшим мотивом выступления Сталина по вопросам языкознания (Н. ВеРт, История советского государства, 345).

33 Общеизвестна оценка «теоретической» практики Сталина, данная Дьёрдем Лукачем: «Сталин так или иначе реагирует на ту или иную совокупность фактов главным образом в тактическом плане, на теорию ложится лишь задача оправдать задним числом тактическое решение как закономерный результат, вытекающий из применения марксистско-ленинского метода». См.: LUKÁCS GYöRGY, A demokratizálódás jelene és jövője. (Budapest: Magvetö Kiadó, 1988), 133. Однако представляется, что в данном конкретном случае идеологические директивы в виде исключения играли более непосредственную роль в выступлении Сталина, чем тактическая реакция. 
и тому подобное, и у него едва ли были сомнения в том, что он сможет внести профессиональный вклад в языкознание. Ему хотелось дать языковедам не только идеологические и властные директивы, но и научные наставления. Однако все это оказалось иллюзией, ведь у Сталина по существу нашлись для лингвистов лишь сообщения двух видов - тривиальности и дилетантские промахи.

Оставив теперь в стороне личность Сталина, подытожим, чем же характеризовались в целом знаменитые или пресловутые «научные» дискуссии пятидесятых годов.

Прежде всего, хотя мы и говорим о научных дискуссиях, очевидно, что они носили в основном административный и идеологический характер. На это указывает уже сам по себе тот факт, что все эти споры без исключения оказались «плодотворными»: они дали однозначных победителей и побежденных. В случае действительно научных споров, когда сталкиваются различные взгляды по профессиональным вопросам, так бывает, естественно, далеко не всегда. Бывает, что спор захлебывается в совершенно неразрешимых противоречиях, в других случаях проясняются конкурирующие взгляды, но спор не решается, а иногда стороны в каком-то отношении приходят к компромиссу. Однако явный идеологический характер научных дискуссий сталинского времени имеет и более конкретные признаки: потерпевшие поражение школы и лица во всех случаях подвергались осуждению прежде всего за философско-идеологические ошибки, причем профессиональные промахи объявлялись лишь логическим следствием последних. Как осужденные, так и получившие предпочтение научные концепции провозглашались «измами» (обычно посредством слов, образованных из имен их представителей); как те, так и другие термины (к последним добавлялась приставка анти-) превращались в формальные клейма. По той же логике положительные «измы» начинали функционировать в качестве широко употребляемых хвалебных эпитетов. Осужденных ученых часто совершенно искусственно объединяли в группировки, внушая тем самым, что их деятельность якобы была скоординированным нападением на советскую науку. Казалось, что споры проходили в демократической атмосфере, но их исход во всех случаях был предопределен (конечно, не всегда с точки зрения участников, хотя в ряде случаев можно предположить и такое). ${ }^{34}$ Помимо проведения идеологических границ, в большинстве

34 А. Б. Кожевников указывает на то, что дискуссий, возникших на местном уровне, было гораздо больше и считает, что одной из их характерных черт было то, что 
случаев называлось лицо, занимающее главное положение в данной научной отрасли, Великий Основатель (Павлов, Мичурин и т. д.), конечно, если такой авторитет в данной научной дисциплине не был задан уже заранее (как в случае классиков марксизма, конечно, включая и Сталина). Бросается в глаза и личная конститутивная (инициативная и контролирующая) роль Сталина; как уже упоминалось выше, в ряде случаев может быть доказано, что он собственноручно редактировал решающие доклады и статьи. Административный характер хорошо просматривается в заботливом отборе участников дискуссий, в заранее определенном сценарии их проведения, в буквально ритуальном применении схем критики и самокритики, ${ }^{35}$

они почти всегда инициировались самими учеными, чтобы с помощью власти победить своих конкурентов, и лишь от непредсказуемых обстоятельств зависело то, в какие дискуссии вмешивалась власть, а какие оставались нерешенными за отсутствием такого вмешательства. В этом смысле Кожевников рассматривает отношение властью к научными дискуссиям как хаотичное и высказывает мнение, что то, что на микроуровне кажется предопределенным, на макроуровне может иметь непредвиденные результаты. См.:A. KoJeVnIKov, «Toward a Post-Cold War Historiography (A Reply to David Joravsky)», Russian Review 57, no. 3 (1998): 455-459). DOI: https:// doi.org/10.1111/1467-9434.00035 Я не совсем согласен с этой интерпретацией и вскоре изложу свою собственною, но хотел бы отметить, что здесь эпитет «предопределенный» применяется мной именно к тем дискуссиям, в которые власть действительно вмешивалась.

35 В своей цитированной выше работе Кожевников убедительно показывает, что эти схемы (совещания, дискуссии, критика и самокритика, свободные споры, но обязательные постановления и т. д., и т. п.) в значительной степени проистекали из жизни партии, поведенческих норм внутрипартийной демократии (из витгенштейновских «языковых игр»), в рамках которой они первоначально предназначались, по крайней мере номинально, в качестве площадок для критики «снизу» и носили определенный ритуальный характер (традиционные формы поведения, деятельность, укрепляющая групповое самосознание, акты с сакральным смыслом и т. д.). Конечно, более подробного исследования заслуживает вопрос, в какой степени они наложились на общие формы функционирования научной деятельности, и, с другой стороны, насколько заимствование этих поведенческих норм, независимо от субъективных убеждений затронутых лиц, может считаться экзистенциальными формами, добровольно принятыми участниками дискуссий, и насколько оно стало результатом давления общественных обстоятельств. Довольно очевидна возможность аналогии между понимаемом в этом смысле уподоблением науки партийной деятельности и едва ли добровольным и спонтанным внедрением милитарных структур в педагогику (см. практику Макаренко). Если при этом мы учтем еще и такие явления, как конструкторские бюро тюремного типа (шараги, шарашки), организованные почти по пенитенциарной логике с целью концентрации творческой деятельности в принципе юридически свободных интеллигентов, то, как кажется, интерпретация упомянутых выше поведенческих форм в качестве по существу добровольно принятых и отрепетированных ритуалов, мягко говоря, нуждается в углублении. 
в немедленной, похожей на поучительные притчи публикации и широкой пропаганде результатов и т. д. Подавляющее большинство дискуссий заканчивалось реорганизацией структур данной научной области, а также тяжелыми экзистенциальными последствиями для членов потерпевшей поражение группы ученых.

Если применить эти критерии кдискуссии о марризме, то структурное сходство окажется гораздо более значительным, чем отличия. Уже современники дискуссии имели возможность убедиться в том, что до появления статьи Сталина она имела в основном, а после появления статьи исключительно идеологический характер. Осуждение Марра и его сторонников после поданного Сталиным сигнала большей частью было связано с их позицией по поводу надстроечного и классового характера языка, то есть с наднаучной, идеологической тематикой, все другие их прегрешения, в том числе и строго лингвистические, изображались как логичные следствия этих главных грехов. ${ }^{36}$ Правда, термин «марризм» возник ранее, но именно тогда это наименование, имевшее положительное или нейтральное содержание, стало окончательно одиозным. Предопределенность исхода дискуссии в «Правде» может быть доказано вполне удовлетворительно. В этой истории мы снова видим Сталина в роли редактора (на этот раз - автора) важнейшего документа. Административный характер, заботливый отбор участников, ритуал критики и самокритики, как по инструкции, присутствовали и в дискуссии о языкознании. Естественно, в полной мере была задействована пропаганда, а также были сделаны все требовавшиеся кадровые и организационные выводы. По этим критериям структура дискуссии о марризме стояла ближе всего к структуре дискуссии о генетике, с той формальной разницей, что более ранняя по времени дискуссия проходила не перед глазами широкой публики и смогла стать предметом общей пропаганды только после своего завершения, в то время как полемика о языкознании с самого начала велась на страницах «Правды»; кроме этого, мифологема Великого Основателя, воплотившаяся в образе Мичурина, не имела соответствия в дискуссии о марризме. Однако в конечном итоге это второе различие тоже является лишь мнимым, ведь в этих эпизодах научной жизни Основатель фукционирует не как историческая личность, а как сакрализованный представитель

36 Никого не смутило, что ранее эти взгляды разделялись и противниками учения Mappa. 
монополизированной интерпретации, источник для ритуальных ссылок, персонифицированный объект лояльности. Ясно, что в дискуссии о марризме эта роль досталась самому Сталину. Не случайно почти сразу после завершения дискуссии начали говорить о «сталинской эпохе в языкознании», более того, просто о «сталинском языкознании».

Самое заметное различие между дискуссиями о генетике и языкознании, несомненно, заключалось в их итогах, ведь, по общепринятой в научном общественном мнении оценке, лысенковская дискуссия принесла победу неправильной, а дискуссия о марризме правильной точке зрения. Однако санкционированные результаты дискуссий обычно имели мало общего с выяснением научной истины, и это хорошо подтверждается тем, что за исключением полемики о марризме не было ни одной дискуссии, итоги которой спустя десятьдвадцать лет не были бы признаны (хотя бы отчасти) ошибочными и вредными. Если смысл механизма, запускавшего, подпитывавшего и направлявшего эти дискуссии, состоял в оживлении научных исследований, ${ }^{37}$ то это был крупнейший провал в истории управления наукой. И не вызывает сомнений, что с этой точки зрения течение событий действительно представляется совершенно случайным. Тысячи случайных моментов (выбор времени, политический и иерархический статус инициаторов и затронутых лиц, личные симпатии и интересы партийных руководителей, актуальные требования политики центральной власти и т. д., и т. п.) влияли на то, по поводу каких разногласий, личных или групповых конфликтов, по поводу каких научных достижений, возможно достигнутых без всяких полемических намерений, разворачивалась та или иная контролируемая властью полемика, и кто в ней подвергался осуждению, а кто стяжал лавры победителя. Нельзя даже утверждать, что решающими были мировоззренческие, идеологические предпочтения, ведь такие аргументы могли приводиться обеими противостоящими сторонами (в этом смысле бывало, как, например, и в случае дискуссии о марризме, что именно будущие побежденные бросались в битву

37 Нечто подобное пишет А. Б. Кожевников: А. Б. Кожевников, «Игры сталинской демократии и идеологические дискуссии в советской науке: 1947-1952 гг.», Вопросы истории естествознания и техники (ВИЕТ), по. 4 (1997): 26-58. [Англоязычный вариант статьи: А. KoJEVNIKov, «Rituals of Stalinist Culture at Work: Science and the Games of Intraparty Democracy circa 1948», The Russian Review 57 (January 1998): 25-52]. DOI: 10.1111/0036-0341.00005 
с лучшей экипировкой). С какой стороны ни посмотреть, с точки зрения научности, идеологических аксиом, каких-либо экономических интересов или даже простой логики, эти манипулированные из центра дискуссии в любом случае, несомненно, представляют абсурдную, хаотичную картину.

Вместе с тем это представление о хаотичном функционировании властных механизмов является такой же объективной иллюзией, как и его методологическая противоположность - теория Воплощенного Зла, согласно которой за каждым событием следует искать личные манипуляции свирепого и непредсказуемого Сталина. Нельзя отрицать, что как раз в упомянутых выше случаях явно видна роль Сталина, который часто выступает конкретным инициатором происходящего, грубо вмешивается в ход событий, дает указания и принимает решения. Но во всех этих случаях он на самом деле не изобретает, а лишь приводит в действие самодвижущийся механизм политического контроля. Кстати, в этом механизме практически отсутствуют специфически научные моменты, он представляет собой лишь конкретную форму проявления государственного интереса в режиме сталинского типа. Тем более, что такова же структура и логика самой науки. Структура советской науки с характерным для нее разделением высшего образования и научных исследований, созданием огромных, часто монополистических научно-исследовательских институтов, с академией в роли органа государственного управления (псевдоминистерства), копированием военно-бюрократических структур в иерархии учреждений, системой наград, званий, рангов и т. д. демонстрировала ту же пирамидальную дедуктивность, что и структура государства в целом, иначе говоря, она изначально строилась и функционировала в соответствии с логикой управления из центра. В таких условиях говорить о грубом вторжении деспотической власти в возвышенную сферу чистой науки - это чистейшее морализирование: сращивание науки и власти было детерминантом, действующим, полезным, более того, желанным для обеих сторон. ${ }^{38}$ Личность Сталина, конечно, неотделима от гипертрофии

38 Если даже справедливо утверждение, что первоначальным источником научных дискуссий было стремление определенных ученых, школ, кафедр, исследовательских институтов и т. д. освободиться от конкурентов, использовав вмешательство власти, - и во многих случаях это было бы трудно отрицать, - то это нельзя интерпретировать как порочные интриги аморальныхэлементов, просочившихся в область чистой науки, ведь эти механизмы были созданы не ими, и невозможно представить дело так, будто бы их конкуренты удерживали свои позиции не в рамках и не с использованием той 
государства, нельзя отрицать его личную роль в историческом возникновении этого явления, но все же Сталин был самое большее первым среди тех, кто приводил в движение этот механизм, но он не был Перводвигателем. Не Сталин создал систему демократического централизма, а он сам был продуктом этой системы.

На самом деле как хаотичная картина конкретных событий, так и представление о непредсказуемости и произвольном характере роли Сталина немедленно отходят на задний план, уступая место реальной логике событий, как только мы оценим эти процессы с точки зрения характера осуществления власти. Что же в конце концов происходило во всех случаях? Путем сознательного и искусственного обострения конфликтов, обнаруженных или иногда ловко генерированных в данной научной отрасли и научной субструктуре, власть добивалась раскола затронутого научного сообщества на победителей, поставленных в положение монополистов, и экзистенциально (как ученых или даже в самом непосредственном смысле) оттесненных на периферию побежденных. Очевидно, что первостепенная цель этого механизма состояла в том, чтобы одернуть и подчинить власти данную группу интеллигенции. Под угрозой оказывались не только побежденные, но и победители, ведь их победа по существу была подарком власти, за который они должны были платить (прежде всего безусловной лояльностью), и им следовало понимать, что они тоже могли бы, больше того, еще могут стать побежденными. С другой стороны, создание доктринальной и институциональной монополии делала данную отрасль науки более послушной механизму властного управления по сравнению с наблюдавшимся ранее относительным плюрализмом научных школ, учений и учреждений.

Итак, дисциплинарный нажим и концентрация власти - вот в чем состояла истинная скрытая логика контролируемых властью научных дискуссий сталинского времени. Это был не хаос, не каприз, а вытекавшая из актуальных государственных интересов и в обозримой перспективе оказывавшаяся эффективной для власти манипуляционная стратегия. На ход «научных» дискуссий пятидесятых годов несомненно наложила отпечаток личность Сталина, но она лишь усиливала те механизмы, которые функционировали и без нее, и при ее участии.

же самой властной стрктуры. Истинная аморальность, если на этом уровне вообще имеет смысл эта категория, была встроена в сам механизм. 
